\title{
Vlaamse knuffelbeer pak neoliberalisme
}

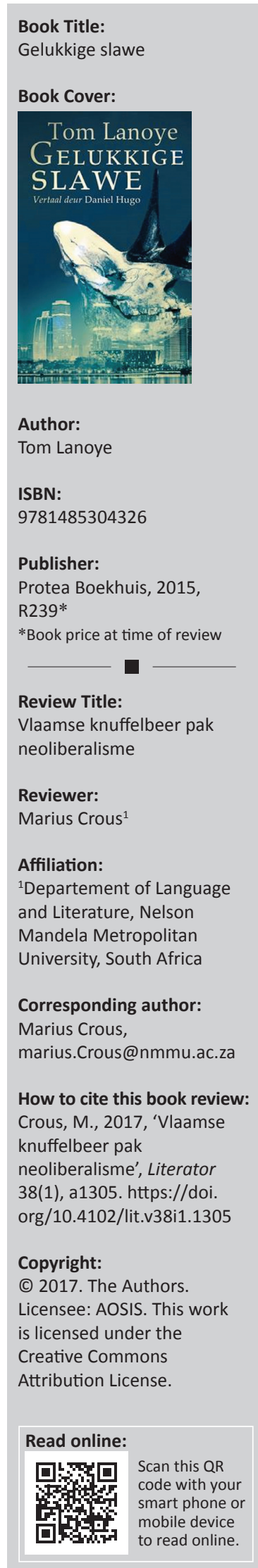

Hierdie roman van Lanoye vertel die verhaal van twee mans wat albei Tony Hanssen heet en wat deur 'n vreemde sameloop van omstandighede in dieselfde hotel in Guangzhou in China beland. Die een was voorheen werksaam op 'n plesierboot en is nou 'n 'katelknaap, geldkoerier, idioot' (bl. 209) in diens van meneer Bo Xiang en sy vrou. Die roman begin trouens in Buenos Aires waar Tony 1 sy plig as katelknaap moet doen en mev Bo Xiang seksueel bevredig. Tony 2, bedrewe met die rekenaar, het uit sy land gevlug omdat hy die bank waarvoor hy gewerk het, bedrieg het. Hóm tref die leser in Mpumalanga aan waar hy aandadig is aan renosterstropery en moord. Die einste twee renosterhorings moet hy na China neem, aangesien meneer Bo Xiang dit as deel van 'n vreemde ritueel laat rasper en 'n tee daarvan drink vir onder meer die verhoging van sy libido en die behandeling van prostaatprobleme.

Die roman word aangebied met ' $n$ proloog en drie dele wat onderskeidelik ondergang, vereniging en hoop heet. Twee leuses (uit Joseph Roth en W. F. Hermans onderskeidelik) lei die roman in: die een praat van getroue vyande en die ander oor die begeerte om soos iemand anders te wees. Laasgenoemde sluit aan by die dubbelportret van Tony wat ons hier aantref. Die dramaturg Lanoye slaan ook deur in die vertellinge met sy plasing van die karakters aan die begin van elke hoofstuk asof hulle in die een of ander stuk sou wees. Vergelyk die volgende:

Ons tref Tony Hanssen op 'n ander kontinent aan, in die middel van die winter wat mense in die land van sy herkoms as 'n veelbelowende lente of 'n genadige herfs sal bestempel. (bl. 141)

Lanoye se roman handel oor die invloed van China op die internasionale politiek; oor die neokoloniale vergrype deur dié moondheid veral in Afrika en die grypsug wat niks en niemand in hulle pad ontsien nie. Dier of mens wat in hul pad staan, word net eenvoudig afgemaai.

Naas hierdie kritiese blik op die materialistiese ingesteldheid van die moderne globale wêreld, wys dit ook vir ons hoe maklik iemand in onguns kan verval by die owerhede aan die roer van sake in so 'n onredelike en ongelyke diktatuur en dan van sy rykdom en posisie ontneem kan word.

Ten dele is die roman patroniserend van aard - veral met betrekking tot die karakter van Khumalo. Bied die swart Afrikaan met sy ubuntu nie net te maklik die oplossing vir alles nie - desondanks sy bewondering vir die prekoloniale Chinese geskiedenis?

Tersaaklik is die resepsie van die oorspronklike Nederlandse teks uit 2013. So skryf Guido Lauwaert op sy blog dat Lanoye 'met de jaren de Vlaamse knuffelbeer geworden [is]', maar dat hierdie roman te wydlopig geword het en onnodige detail bevat. Dit kon aansienlik dunner gewees het. Lauwert se kritiek teen die kru seksualiteit in die teks vind ek eweneens verkwiklik. Wat hy van Lanoye se volgende roman verlang, is: 'Hopelijk eens seksloos. Want met een open gulp wordt het algauw goedkope pulp.' Claudia Zeller vat die essensie van Lanoye se striemende aanval op neoliberale globalisering soos volg saam:

Ondanks alle ellende mag er gelachen worden, ook al is het geen bevrijdende lach. Het is de lach van de dwaas, gevangen in een afbrokkelend, krankzinnig systeem dat hij ondanks alles in stand probeert te houden, want: Een mens moet zich ergens thuis voelen, desnoods in het niets.

Die snelle vloei van die verhaallyn inspireer Wim Huyghebaert om van Lanoye as 'dé literaire evenknie van Quentin Tarantino' te praat.

\section{Literatuurverwysings}

Huyghebaert, Wim, 2013, 'Januskop van bedrog en hebzucht', bekeken 2016-10-15 http://www.cuttingedge.be/boekenstrips/tomlanoye-gelukkige-slaven

Lauwaert, Guido, 2013, 'Tom Lanoye moet dringend vermageren', bekeken 2016-10-15 http://www.knack.be/nieuws/boeken/tomlanoye-moet-dringend-vermageren/article-opinion-104843.html

Zeller, Claudia, 2013, 'Nomaden van een nieuwen orde', bekeken 2016-10-15 http://recensieweb.nl/recensie/nomaden-van-een-nieuweorde/ 